\title{
Compositional variations in calciturbidites and calcidebrites in response to sea-level fluctuations (Exuma Sound, Bahamas)
}

\author{
John J. G. Reijmer · Pauline Palmieri • \\ Ralph Groen
}

Received: 6 September 2010/Accepted: 25 December 2011/Published online: 22 February 2012

(C) The Author(s) 2012. This article is published with open access at Springerlink.com

\begin{abstract}
The compositional variation of Pleistocene carbonate gravity deposits from the Exuma Sound Basin, Bahamas, was determined. Two types of gravity deposit were present in the cores of ODP Leg 101, Site 632A, i.e., calciturbidites and calcidebrites. In analogy with earlier studies, the compositional variations in the calciturbidites could be linked to different sources on the carbonate margin, i.e., platform interior, platform edge, and platform slope. Calciturbidites deposited during interglacial, sealevel highstands show a dominance of non-skeletal grains, largely derived from the platform interior, while calciturbidites of glacial, sea-level lowstands, show a dominance of skeletal platform-edge to platform-slope-derived grains. Thus, the calciturbidite composition can be used to reconstruct the position of absolute sea level. In addition,
\end{abstract}

J. J. G. Reijmer $(\bowtie) \cdot$ R. Groen

Faculty of Earth and Life Sciences, Department of Earth

Sciences, Sedimentology and Marine Geology Division,

VU University Amsterdam, De Boelelaan 1085,

1081 HV Amsterdam, The Netherlands

e-mail: j.j.g.reijmer@vu.nl; john.reijmer@falw.vu.nl

\section{J. J. G. Reijmer}

Faculty of Civil Engineering and Geosciences,

Department of Geotechnology, Delft University of Technology,

Stevinweg 1, 2628 CN Delft, The Netherlands

\section{P. Palmieri}

Laboratoire de Géologie des Systèmes et des Réservoirs

Carbonatés EA 4229, Case 67, Université de Provence

(Aix-Marseille I), 3 place Victor Hugo,

13331 Marseille Cédex 03, France

\section{Present Address:}

R. Groen

Mærsk Olie og Gas A/S, Esplanaden 50,

1263 Copenhagen K, Denmark the mud content of the calciturbidites increased after Marine Isotope Stage 11. In contrast, the composition of the calcidebrites remained unaltered through time and showed a clear dominance of platform-edge-derived sediments during varying sea-level positions. The Bahamian carbonate platform is located in a tectonically stable passive-margin setting and the gravity-flow deposits were laid down in an environment exclusively controlled by eustatic sea-level fluctuations. This study shows that all types of gravity-induced carbonate deposits, calciturbidites, and calcidebrites, were deposited in response to global eustatic sea-level variations. The sediment composition could be linked directly to sediment input from specific facies realms along the carbonate platform margin. Hence, sediment composition analysis is a strong tool that may be used to discriminate between gravity-induced deposition triggered by eustatic sea-level changes and that related to tectonic events, when analyzing resedimentation processes in sedimentary basins.

Keywords Sediment gravity flows - Calciturbidites . Calcidebrites - Sediment composition - Bahamas . Caribbean

\section{Introduction}

Sediment production and gravity flows

Sediment production on flat-topped carbonate platforms and sediment export are affected by relative fluctuations in sea level that flood or expose the top of the platform. These sea-level variations may be either climate-induced or related to tectonic processes or a combination of both. In addition, a large variety of regional and local climatic 
factors might influence the production on carbonate platforms such as water temperature, nutrient variation, light penetration, salinity fluctuation, currents, tides, and oxygen variation, but also monsoon-driven oceanographic variations can severely affect the carbonate production areas.

Periplatform sediments, a mix of shallow-water and pelagic input, are reliable archives of changes in the depositional conditions on shallow-water platforms. Cyclic variations in the aragonite content of periplatform sediments deposited in the deep-water realm near flat-topped carbonate platforms, for example, could clearly be related to exposure and flooding of the shallow-water production areas, the "highstand shedding" model with high sediment production and export during sea-level highstands and low sediment production and export during lowstands in sea level (Droxler et al. 1983; Mullins et al. 1984; Reijmer et al. 1988; Schlager et al. 1994). The vast quantity of excess bank-top production and the limited storage volume in the shallow-water realm provides large volumes of sediment available for off-bank export (Neumann and Land 1975; Mullins et al. 1984; Roth and Reijmer 2004). Offbank transport of coarse-grained material occurs mainly during the passage of storms along the leeward, open margin of the Little Bahama Bank (Hine et al. 1981). Tidal currents and normal wave action cause only minor sand movement, but relatively weak currents are able to winnow fine-grained shallow-water sediment and transport it to the slope (Hine et al. 1981; Roth and Reijmer 2004). Off-bank sediment transport of fine-grained aragonite is forced by tide- and wind-driven advection and by "density cascading" (Wilson and Roberts 1995; Roth and Reijmer 2005). Once transported off-bank, the sediments are transported down slope mainly by turbidity currents and debris flows (Mullins et al. 1984).

The compositional variations of gravity-flow deposits have been used to link their composition to either facies alterations within the shallow-water realm of carbonate platforms or to variations in sea level exposing or flooding different sediment production areas (Late Quaternary, Tongue of the Ocean, Bahamas: Haak and Schlager 1989; Paleogene, SE Spain: Everts 1991; Triassic, Northern Calcareous Alps, Austria: Reijmer et al. 1991; Dinantian, Germany; Herbig and Bender 1992; Plio-Pleistocene, Exuma Sound, Bahamas: Reijmer et al. 1992). Other studies have revealed the presence of small- and large-scale cycles in clinoform composition of the carbonate platforms of the Vercors (SE France) (Everts and Reijmer 1995; Everts et al. 1999), and the Dürrenstein/Pico di Vallandro (Dolomites, Italy; Reijmer 1998). It was shown that larger cycles parallel the large-scale rhythm of progradation and retreat of the clinoforms, whereas the smaller cycles were probably related to small-scale shallowing-upward cycles on the platform top. On a finer scale, Reijmer et al. (1991,
1994) demonstrated that the periodicity within the composition of a sequence of Triassic calciturbidites could be related to the small-scale sedimentation cycles on the platform, the so-called Lofer cycles (20-100 ka), fifth- and sixth-order-scale cycles sensu Vail et al. (1991).

In their analysis of seismic profiles and short cores within Exuma Sound, Crevello and Schlager (1980) showed the presence of three sequences with gravity-displaced sediments; two calciturbidites with limited aerial extent, 120 and $400 \mathrm{~km}^{2}$, respectively, and one debris flow deposit with a widespread occurrence, approx $6,400 \mathrm{~km}^{2}$, and a relatively large sediment volume in excess of $10^{17} \mathrm{~m}^{3}$. The calciturbidites contain Halimeda plates and ooids. The debrite contains clasts derived from the edge of the platform, a mixture of shallow-water detritus and clasts of pelagic chalk. Crevello and Schlager (1980) proposed that the debris flow most likely was triggered during a sea-level lowering during which a $20-30 \mathrm{~km}$ wide segment of the upper slope and platform margin became displaced. In their study, Spence and Tucker (1997) reviewed the occurrence of calcidebrites and calciturbidites and identified several processes that could trigger the initiation of these sediment redeposition events, e.g., wave-base lowering during regression, relative overpressure of confined aquifers during regression, or the drainage of pore fluids when the platform top becomes exposed. Increased pressure on the upper slope sediment stack during transgression was a mechanism proposed by Andresen et al. (2003) and Lantzsch et al. (2007). Overpressure generated by seismicity, or overpressures created by tsunami waves were other processes proposed by Spence and Tucker (1997). In their detailed overview of the occurrence of a large series of fossil calciclastic submarine fans, Payros and Pujalte (2008) showed that in the majority of the case studies, the deposition of calcidebrites is linked to tectonic events triggering the redeposition of sediments.

Hence, a large series of processes have been proposed to explain the initiation of sediment redeposition events. In this study, we will show that (1) global eustatic variations alone can produce all types of gravity-induced carbonate deposits, calcidebrites and calciturbidites, and (2) that not only the composition of calciturbidites but also of calcidebrites can be related to input from a specific facies realm along the carbonate platform margin.

\section{Regional geology and geography}

The Pleistocene calciturbidites and calcidebrites studied were deposited in the Exuma Sound Basin, Bahamas (Fig. 1). The Bahamas are a vast system of carbonate platforms $\left(150,000 \mathrm{~km}^{2}\right)$ stretching in a NNW-SSE direction. Reefs, ooid shoals, or low-relief islands border the shallow-water areas of the platforms in which 


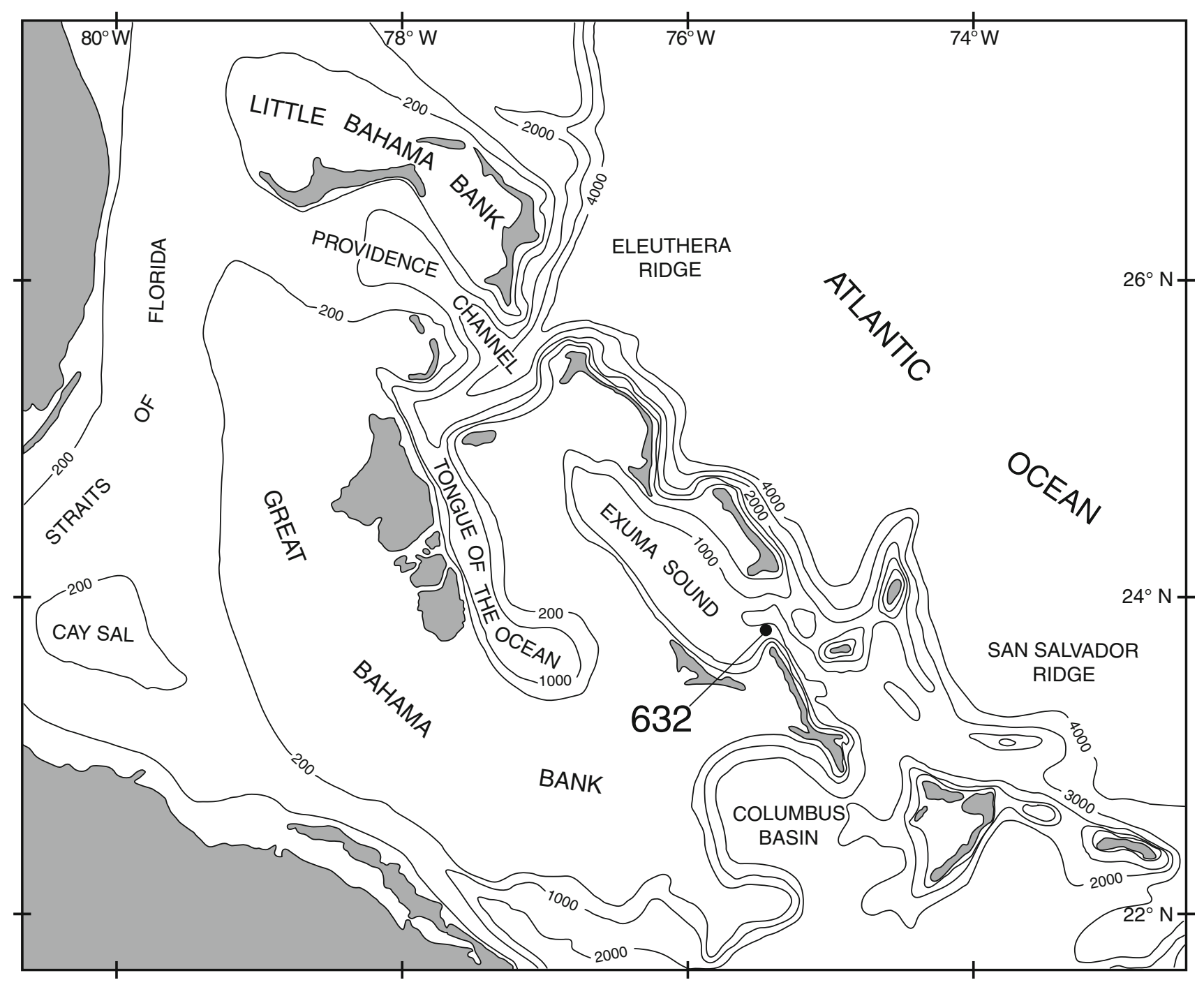

Fig. 1 Location map Site 632, ODP Leg 101, Exuma Sound. Water depth contours in meters. Dark grey pattern indicates islands. Modified from Reijmer et al. (1988)

non-skeletal mud-rich sediments dominate (Purdy 1963a, b; Reijmer et al. 2009; Fig. 2). The edge of the shallowwater areas marks a transition to steeply inclined slopes, with slope angles of up to $90^{\circ}$, the so-called "wall" (Wilber et al. 1990). As a result of this particular topography, the production of carbonate sediments on the platforms is strongly influenced by relative variations in sea level, because only small changes in sea level will expose the shallow-water areas. Great Bahama Bank surrounds three basins: the Tongue of the Ocean, Columbus Basin, and Exuma Sound. The last one is a $40-65 \mathrm{~km}$ wide, $200 \mathrm{~km}$ long elongated basin, with a depth of $1,200 \mathrm{~m}$ in the north to almost $2,000 \mathrm{~m}$ in the south (Crevello and Schlager 1980). The Plio/Pleistocene-Holocene sediments in Exuma Sound are characterized by an alternation of periplatform oozes and calciturbidites and calcidebrites (Crevello and Schlager 1980; Reijmer et al. 1988, 1992).

\section{Materials and methods}

Samples

An 83.8-m-long sequence of hydraulic piston cores from ODP Hole 632A was studied. This hole was drilled in Exuma Sound at $23^{\circ} 50.44^{\prime} \mathrm{N}, 76^{\circ} 26.13^{\prime} \mathrm{W}$, at a water depth of $1,996 \mathrm{~m}$ (Fig. 1), to a total depth of $141 \mathrm{mbsf}$. Recovery of the interval from 0 to 93.9 mbsf was $73.4 \%$ (Austin $\mathrm{Jr}$ et al. 1986). The sediments present in the cores were dated as Late Miocene to Pleistocene in age (Austin Jr et al. 1986). The detailed lithostratigraphy and assignment of individual marine isotope stages (MIS) of ODP Hole 632A sediments analyzed in this study is based on the aragonite stratigraphic interpretation of Reijmer et al. (1988) and on oxygen isotope stratigraphy from $G$. sacculifer within the same sediments (Reijmer, unpublished data). 


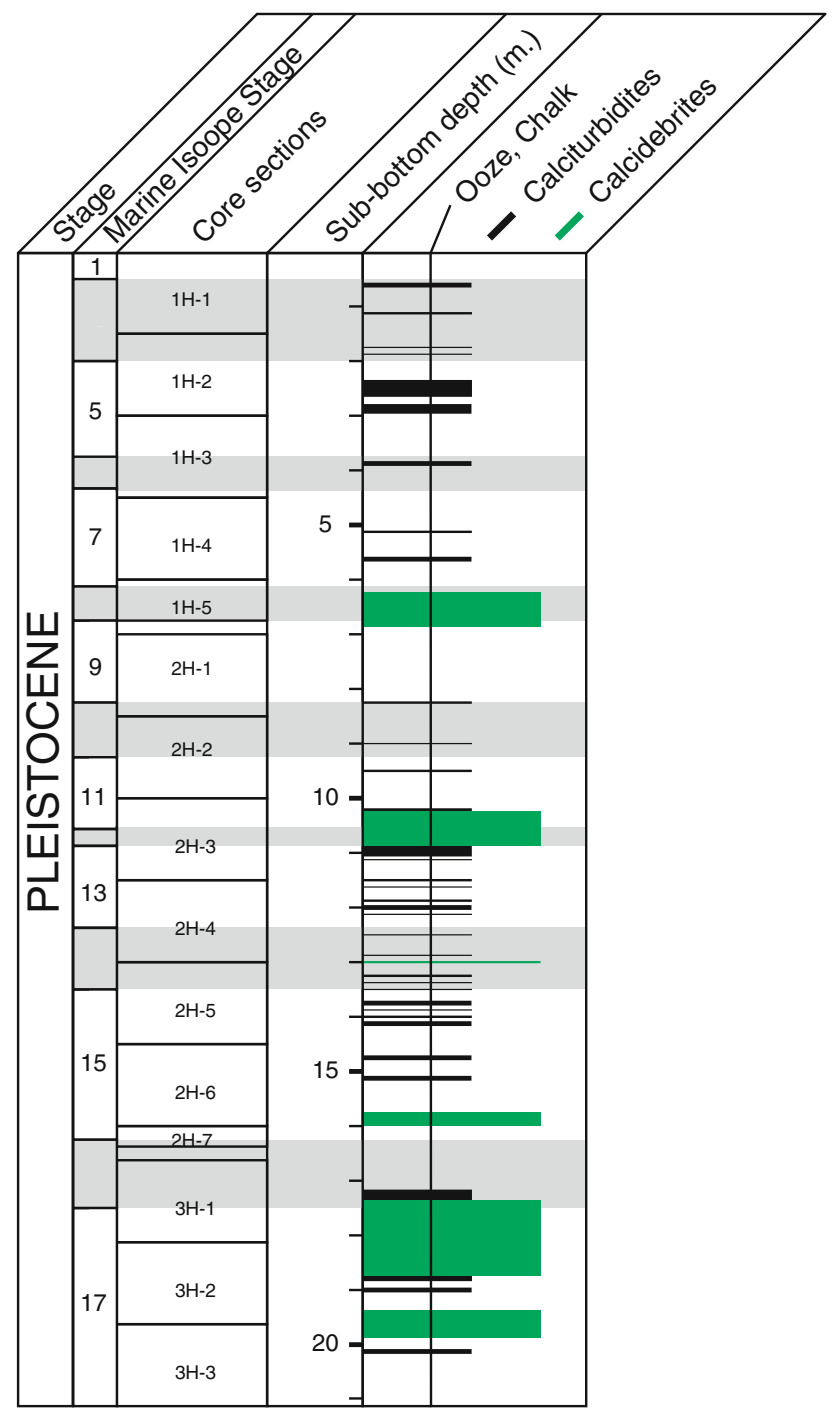

Fig. 2 Lithostratigraphy of Exuma Sound. Depth variation of lithology (turbidite or debris flow, and chalk or ooze) for the upper $35.9 \mathrm{~m}$ of Hole 632A, ODP Leg 101. The assigned oxygen isotope stages are after Reijmer et al. (1988) and Reijmer (unpublished data)

Based on the shipboard core descriptions (Austin Jr et al. 1986) and our own core descriptions, samples were taken from the individual gravity-flow deposits (calciturbidites and calcidebrites) present in the piston cores (Fig. 2). Identification of calciturbidites and calcidebrites was based on shipboard core descriptions and core photographs and personal core descriptions during sampling. We used the criteria described by Droxler and Schlager (1985) for identifying turbidite layers and debrites. Base and tail of turbidite and debrite beds commonly were identified by color differences. In total, 130 samples were taken from the upper 16 sediment cores, down to a depth of $36 \mathrm{~m}$ subbottom.

The white to light grey color of the calciturbidites and calcidebrites differs from the various shades of white to very pale brown color of the periplatform ooze, the background sediment, and makes their recognition in the cores fairly straightforward. Most bases of the unlithified turbidite grainstones are planar. Grainstone layers show internal grading and some of them even show a gradual transition into the overlying periplatform ooze. The grain- to rudstones are interpreted as calciturbidites and calcidebrites and their position in the cores could be constrained with centimeter precision. A total of 130 thin-sections taken from calciturbidites and calcidebrites were studied from these cores (Palmieri 2006, 2007). The calcidebrites all consist of unlithified rud- to grainstones and the calciturbidites consist of unlithified grain- to packstones.

Analytical methods

\section{Microfacies}

The textures of 130 thin-sections were defined following the classification scheme of Dunham (1962) and Embry and Klovan (1971). The nature of the grains (various bioclasts, lithoclasts, pellets, peloids, ooids, minerals) and the matrix (micrite and sparite) were used as variables in the quantitative analysis. In total, five textures could be identified in the thin-sections: (1) three different textures within the calciturbidites: packstone, grainstone, and wackestone, which only occur in stages younger than marine isotope stage 11 ; (2) two different textures within the calcidebrites: floatstone and rudstone.

The composition of the thin-sections was determined based on the point-counting method defined by Chayes (1956). The variables used in this method are based on the identification of the different constituents during the qualitative description. In total, 200 points were counted in each thin-section.

Fifteen different groups of constituents were encountered in the thin-sections: matrix with (1) micrite, and (2) sparite; skeletal grains like (3) planktic foraminifers (family Globigerinidae), (4) pteropods, (5) green algae, mainly type Halimeda, (6) red algae (coralline algae: Lithothamnion), (7) echinoderms, (8) sponges, (9) ostracods, (10) corals, (11) benthic foraminifers (Peneroplis sp., Gypsina sp., Homotrema rubrum and others), (12) bivalves, and (13) bryozoans; and non-skeletal grains like (14) ooids, and (15) pellets and peloids. Platform or slope-derived lithoclasts (16) were also found, as well as (17) pores, and (18) non-determinable grains, the origin of which could not be determined due to poor preservation or strong micritization. Constituents (3)-(13) represent skeletal elements present within the sedimentary system of the Bahamas; variables (14) and (15) are the non-skeletal elements. The constituent's diversity agrees with the grains comprising the point-count groups defined by Haak and Schlager 
(1989) analyzing calciturbidites from the Tongue of the Ocean, Bahamas.

\section{Results}

Introduction

The attribution of the sediments to MIS 1 to 23 was based on the glacial-interglacial aragonite stratigraphy established by Reijmer et al. (1988), and was reconfirmed by interpretation of stable isotope data measured on $G$. sacculifer on the same samples (Reijmer unpublished data).

The stratigraphic analysis shows that the calciturbidites are more frequent and thicker in interglacial stages MIS 23 to 1, compared to the glacial stages MIS 22 to 2 (Fig. 2: see also Reijmer et al. 1988). The calcidebrites are only observed during the transitions from MIS 23 to MIS 22, MIS 17 to MIS 16, MIS 13 to MIS 12, and MIS 9 to MIS 8 (Fig. 2). They are not present at younger MIS transitions. In general, the gravity-induced deposits, calciturbidites, and calcidebrites, are more frequent in MIS 24 to 11 than in the younger stages following MIS 11. In addition, the thickness of the gravity-flow deposits tends to decrease from MIS 23 to MIS 1, from over $1.5 \mathrm{~m}$ on average in MIS 23 to several centimeters in MIS 1.

The statistical analysis of the point-count results is presented in various histograms (Figs. 3, 4), pie charts (Figs. 3, 4, 6) and Table 1. The individual variables are regrouped in the following categories: matrix, pelagic material and platform-derived material (Figs. 3, 4). The
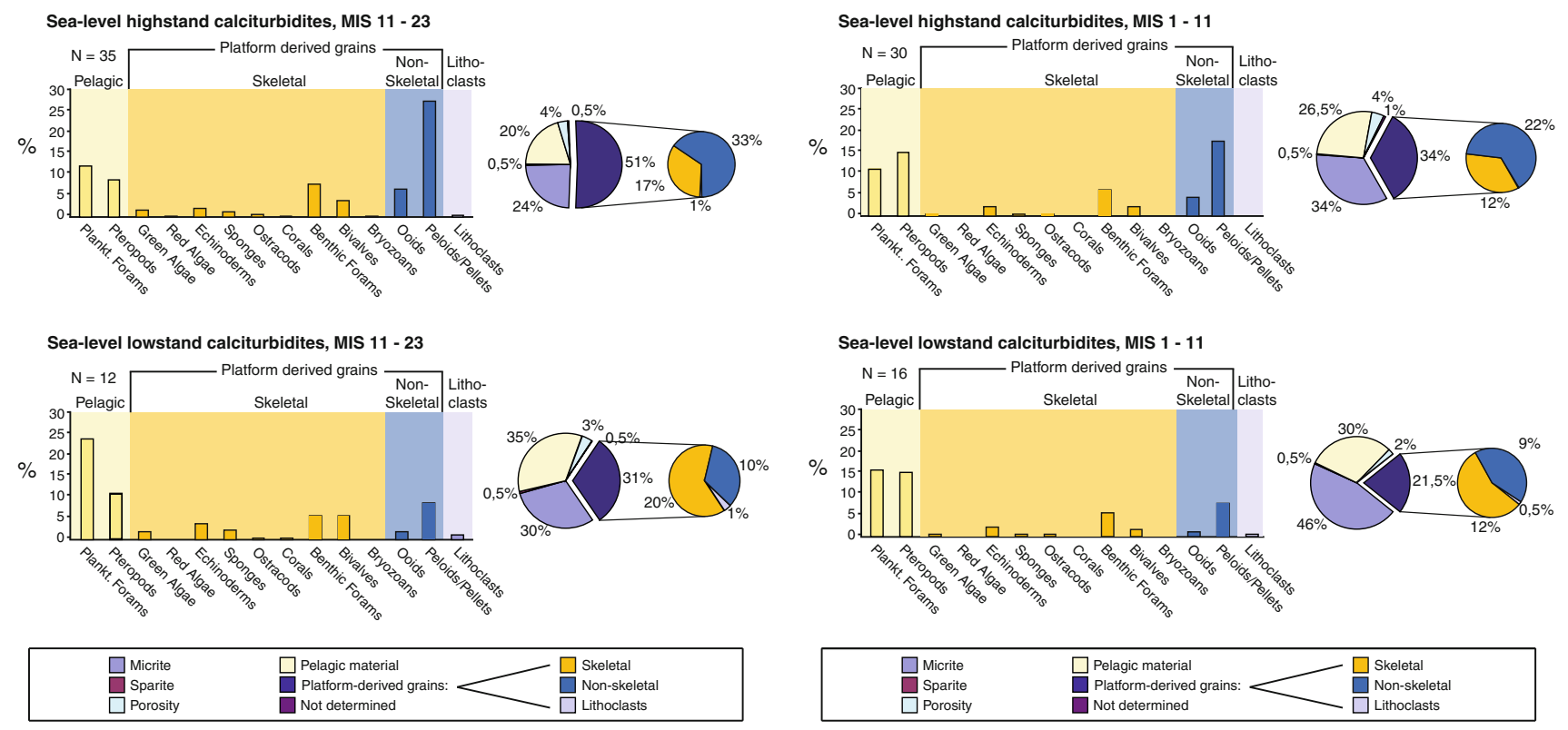

last category comprises skeletal and non-skeletal elements, as well as lithoclasts. Based on the averages for each variable counted in the thin-sections, the gravity-flow deposits of the Bahamas could be subdivided into eight groups (Table 1). This grouping is a function of the nature of the sediment, i.e., calciturbidite or calcidebrite, the MIS in which they were deposited, glacial or interglacial, and the timing of their deposition, before or after MIS 11.

\section{Calciturbidites of MIS 11 to 23}

\section{Sea-level highstand calciturbidites}

Micrite comprises almost $24 \%$ of the total counts, while sparite remains below $1 \%$. Benthic foraminifers with almost $10 \%$ dominate the skeletal input and pellets/peloids form the major part of the non-skeletal grains. Less than $1 \%$ of the grains remained undetermined (Figs. 3, 5a).

These calciturbidites show a predominance of matrix, $24.5 \%$, and pelagic-derived input, $21 \%$ (Table 1; Fig. 6). Platform-derived material forms slightly over half the material of the calciturbidite $(51 \%) ; 33 \%$ of which are nonskeletal elements, minor skeletal grains $(17 \%)$ and lithoclasts $(1 \%)$.

\section{Sea-level lowstand calciturbidites}

Micrite once again dominates the matrix with $30 \%$ of the counts, while sparite reaches less than $1 \%$. Planktic foraminifers surpass $20 \%$, while pteropods represent $9 \%$ of the grains. Bivalves and benthic foraminifers represent the

Fig. 3 Composition of interglacial and glacial calciturbidites 

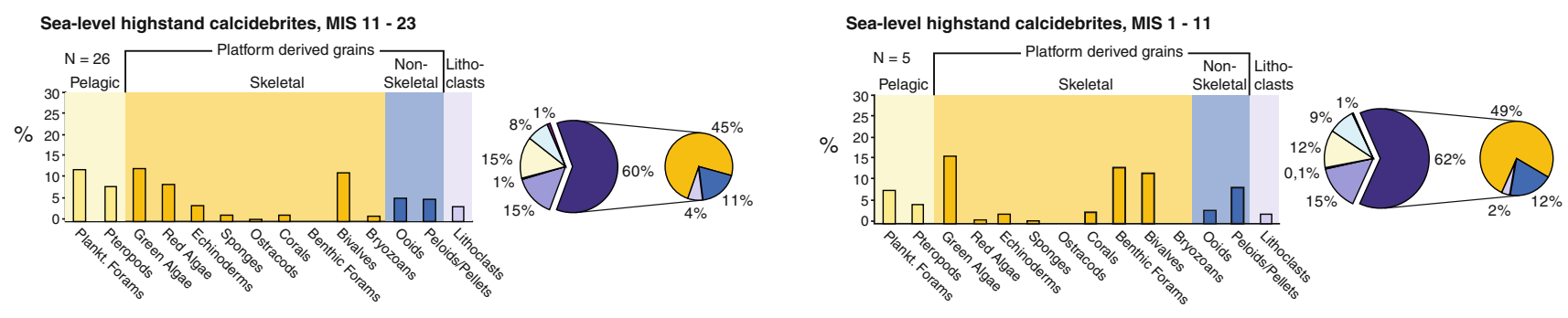

Sea-level lowstand calcidebrites, MIS 11 - 23

Sea-level lowstand calcidebrites, MIS 1 - 11
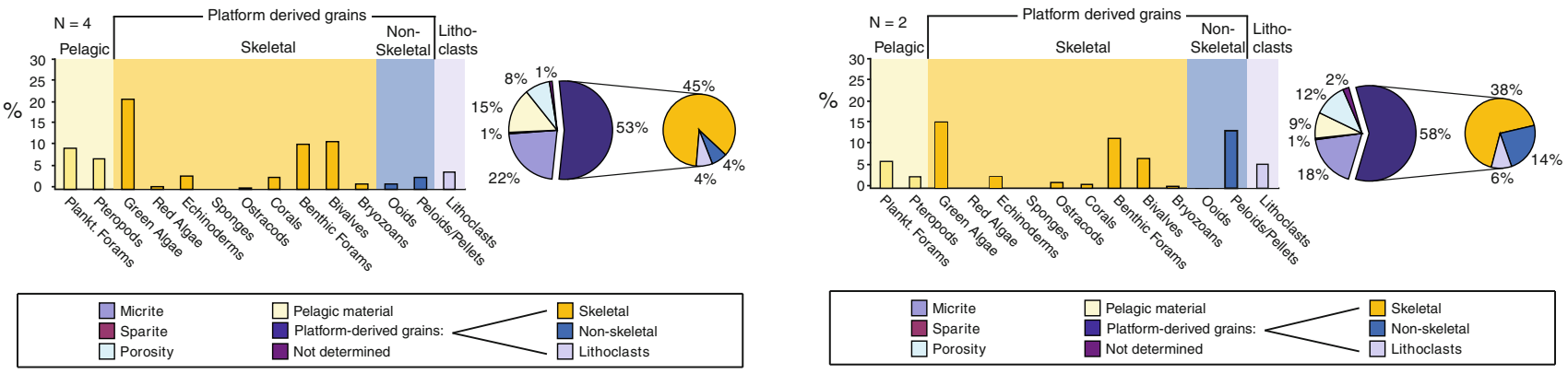

Fig. 4 Composition of interglacial and glacial calcidebrites

Table 1 Point count summary

\begin{tabular}{|c|c|c|c|c|c|c|c|c|c|}
\hline & \multirow{2}{*}{$\begin{array}{l}\text { Micrite } \\
(\%)\end{array}$} & \multirow{2}{*}{$\begin{array}{l}\text { Sparite } \\
(\%)\end{array}$} & \multirow{2}{*}{$\begin{array}{l}\text { Dominant skeletal } \\
\text { grains }\end{array}$} & \multirow{2}{*}{$\begin{array}{l}\text { Dominant } \\
\text { non- } \\
\text { skeletal } \\
\text { grains }\end{array}$} & \multirow{2}{*}{$\begin{array}{l}\text { Matrix } \\
(\%)\end{array}$} & \multirow{2}{*}{$\begin{array}{l}\text { Pelagic } \\
(\%)\end{array}$} & \multicolumn{3}{|c|}{ Platform-derived grains } \\
\hline & & & & & & & $\begin{array}{l}\text { Skeletal } \\
(\%)\end{array}$ & $\begin{array}{l}\text { Non- } \\
\text { skeletal } \\
(\%)\end{array}$ & $\begin{array}{l}\text { Clasts } \\
(\%)\end{array}$ \\
\hline $\begin{array}{l}\text { Sea-level highstand } \\
\text { calciturbidites }\end{array}$ & 24 & 0.5 & Benthic foraminifers & $\begin{array}{l}\text { Pellets/ } \\
\text { peloids }\end{array}$ & 24.5 & 20 & 17 & 33 & 1 \\
\hline \multicolumn{10}{|l|}{ MIS 11-23 } \\
\hline $\begin{array}{l}\text { Sea-level lowstand } \\
\text { calciturbidites }\end{array}$ & 30 & 0.5 & Planktic foraminifers and pteropods & Pellets & 30.5 & 35 & 19.8 & 10.3 & 1 \\
\hline \multicolumn{10}{|l|}{ MIS 11-23 } \\
\hline $\begin{array}{l}\text { Sea-level highstand } \\
\text { calciturbidites }\end{array}$ & 34 & 0.5 & $\begin{array}{l}\text { Benthic foraminifers, bivalves, and } \\
\text { sponges }\end{array}$ & $\begin{array}{l}\text { Pellets, } \\
\text { ooids }\end{array}$ & 34.5 & 26.5 & 12 & 22 & 0 \\
\hline \multicolumn{10}{|l|}{ MIS $1-11$} \\
\hline $\begin{array}{l}\text { Sea-level lowstand } \\
\text { calciturbidites }\end{array}$ & 46 & 0.3 & $\begin{array}{l}\text { Benthic foraminifers, bivalves, and } \\
\text { echinoderms }\end{array}$ & Pellets & 46.3 & 30 & 12 & 9 & 0.5 \\
\hline \multicolumn{10}{|l|}{ MIS 1-11 } \\
\hline $\begin{array}{l}\text { Sea-level highstand } \\
\text { calcidebrites }\end{array}$ & 15 & 1 & $\begin{array}{l}\text { Green algae, red algae, bivalves, and } \\
\text { benthic foraminifers }\end{array}$ & $\begin{array}{l}\text { Pellets, } \\
\text { ooids }\end{array}$ & 16 & 15 & 45 & 11 & 4 \\
\hline \multicolumn{10}{|l|}{ MIS 11-23 } \\
\hline $\begin{array}{l}\text { Sea-level lowstand } \\
\text { calcidebrites }\end{array}$ & 22 & 1 & $\begin{array}{l}\text { Green algae, bivalves, and benthic } \\
\text { foraminifers }\end{array}$ & $\begin{array}{r}\text { Pellets, } \\
\text { ooids }\end{array}$ & 23 & 15 & 45 & 4 & 4 \\
\hline \multicolumn{10}{|l|}{ MIS $11-23$} \\
\hline $\begin{array}{l}\text { Sea-level highstand } \\
\text { calcidebrites }\end{array}$ & 15 & 1 & $\begin{array}{l}\text { Green algae, bivalves, benthic } \\
\text { foraminifers, and corals }\end{array}$ & $\begin{array}{r}\text { Pellets, } \\
\text { ooids }\end{array}$ & 16 & 12 & 49 & 12 & 2 \\
\hline \multicolumn{10}{|l|}{ MIS $1-11$} \\
\hline $\begin{array}{l}\text { Sea-level lowstand } \\
\text { calcidebrites }\end{array}$ & 18 & 1 & $\begin{array}{l}\text { Green algae, benthic foraminifers, and } \\
\text { bivalves }\end{array}$ & Pellets & 19 & 9 & 38 & 14 & 6 \\
\hline MIS 1-11 & & & & & & & & & \\
\hline
\end{tabular}

Summary of the variations in the main groups of grains for the calciturbidites and calcidebrites 

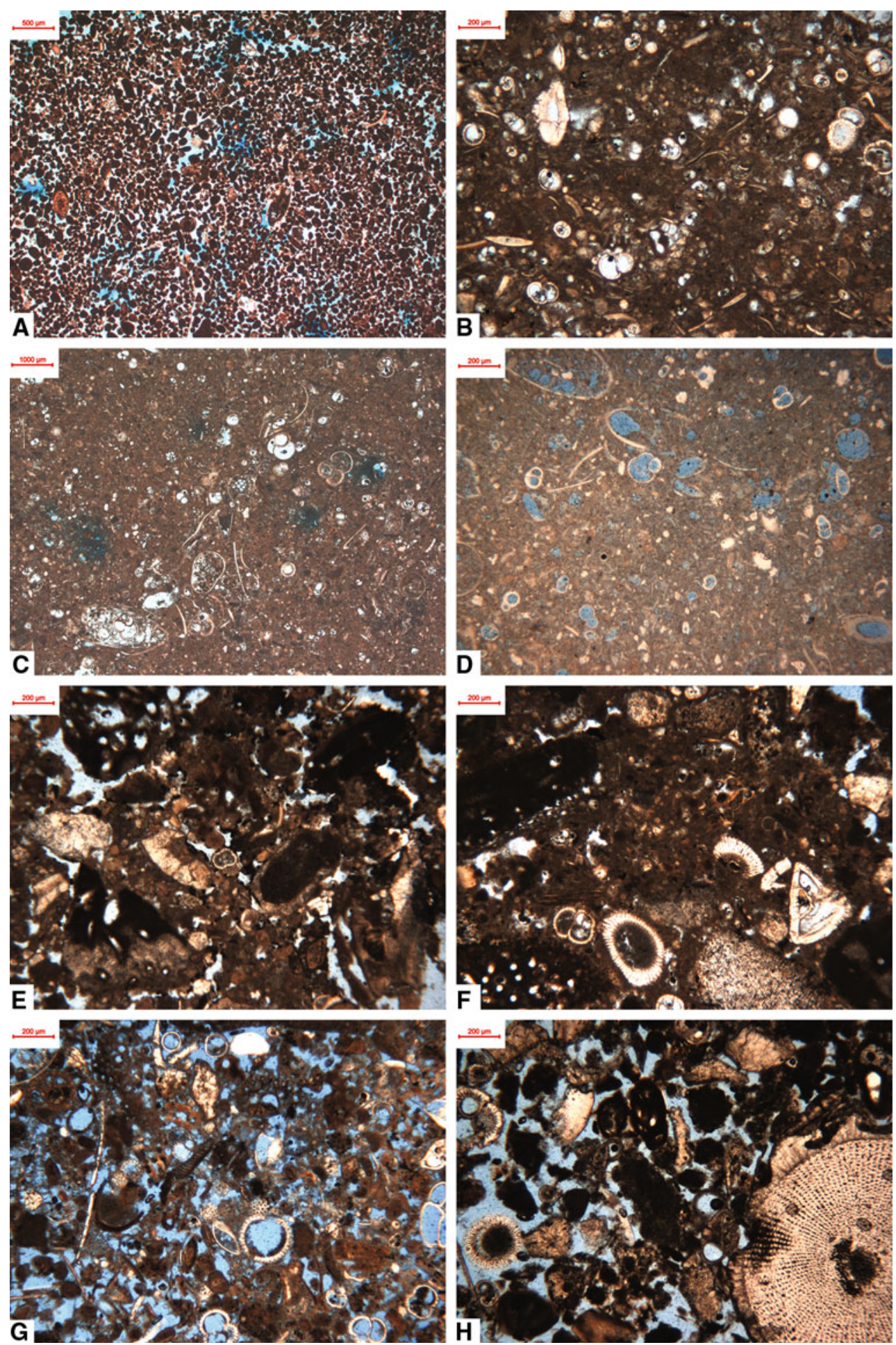

Fig. 5 Compositional variation in calciturbidites and calcidebrites. a Highstand calciturbidite MIS 10-23, scale $100 \mu \mathrm{m}$. Peloidal grainstone with some benthic foraminifers. Sample ODP Leg 101, 632A2-6, 144-146. b Lowstand calciturbidite MIS 10-23, scale $100 \mu \mathrm{m}$. Skeletal, planktic-foram-rich packstone. Sample ODP Leg 101, 632A3-4, 47-49. c Highstand calciturbidite MIS 1-10, scale $100 \mu \mathrm{m}$. Note high mud content mixed with planktic foraminifers and some skeletal debris. Sample ODP Leg 101, 632A-1-1, 26-28. d Lowstand calciturbidite MIS $1-10$, scale $100 \mu \mathrm{m}$. Mix of large planktic foraminifers embedded in a muddy matrix. Sample ODP Leg 101, 632A-1-3/

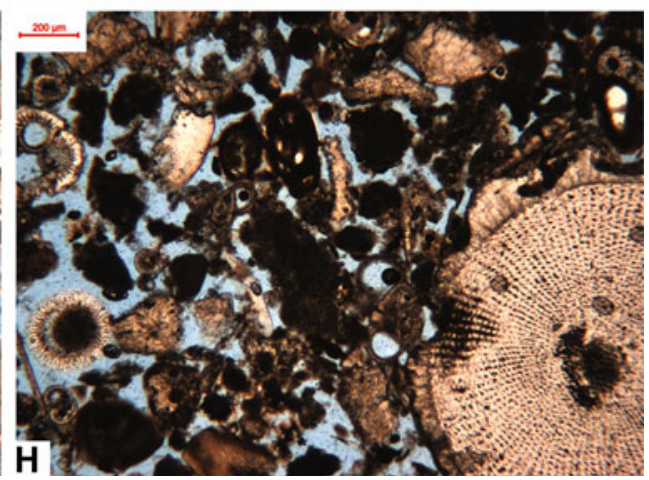

129-131. e Highstand calcidebrite MIS 10-23, scale $100 \mu \mathrm{m}$. Skeletal, carbonate-clast-rich packstone. Sample ODP Leg 101, 632A-_3-cc, 165-167. f Lowstand calcidebrite MIS 10-23, scale $100 \mu \mathrm{m}$. Skeletal, carbonate-clast-rich packstone. Sample ODP Leg 101, 632A-2-3, 66-68. g Highstand calcidebrite MIS 1-10, scale $100 \mu \mathrm{m}$. Skeletal, carbonate-clast-rich packstone. Planktic and benthic foraminifers are also present. Sample ODP Leg 101, 632A-1-5, 66-67. h Lowstand calcidebrite MIS 1-10, scale $100 \mu \mathrm{m}$. Skeletal, carbonate-clast-rich packstone. Sample ODP Leg 101, 632A-1-5, 75-77 
Fig. 6 Pie charts summarizing the input of the facies origin of platform-derived grains in calciturbidites and calcidebrites at Site 632A, ODP Leg 101

Sea-level highstand calciturbidites

Sea-level lowstand calciturbidites

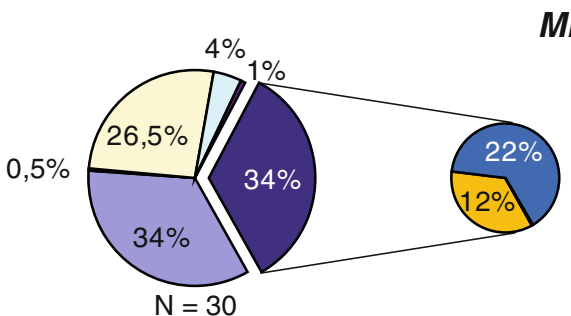

MIS 1 - 11

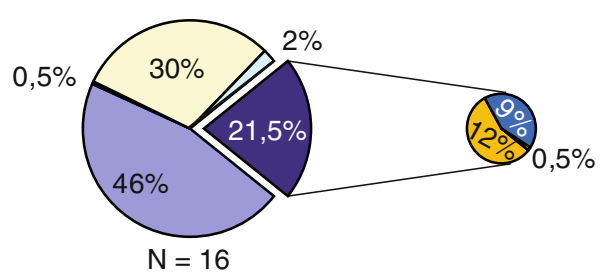

MIS 11 - 23

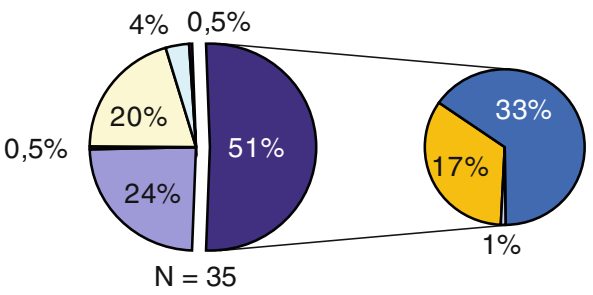

Sea-level highstand calcidebrites

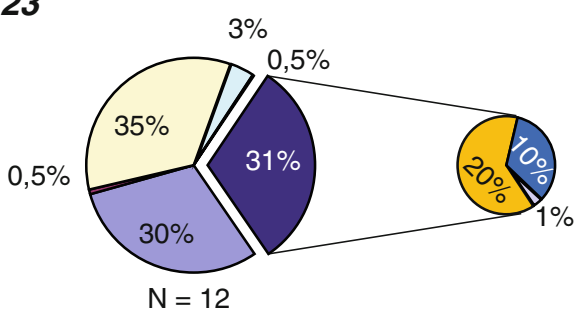

Sea-level lowstand calcidebrites
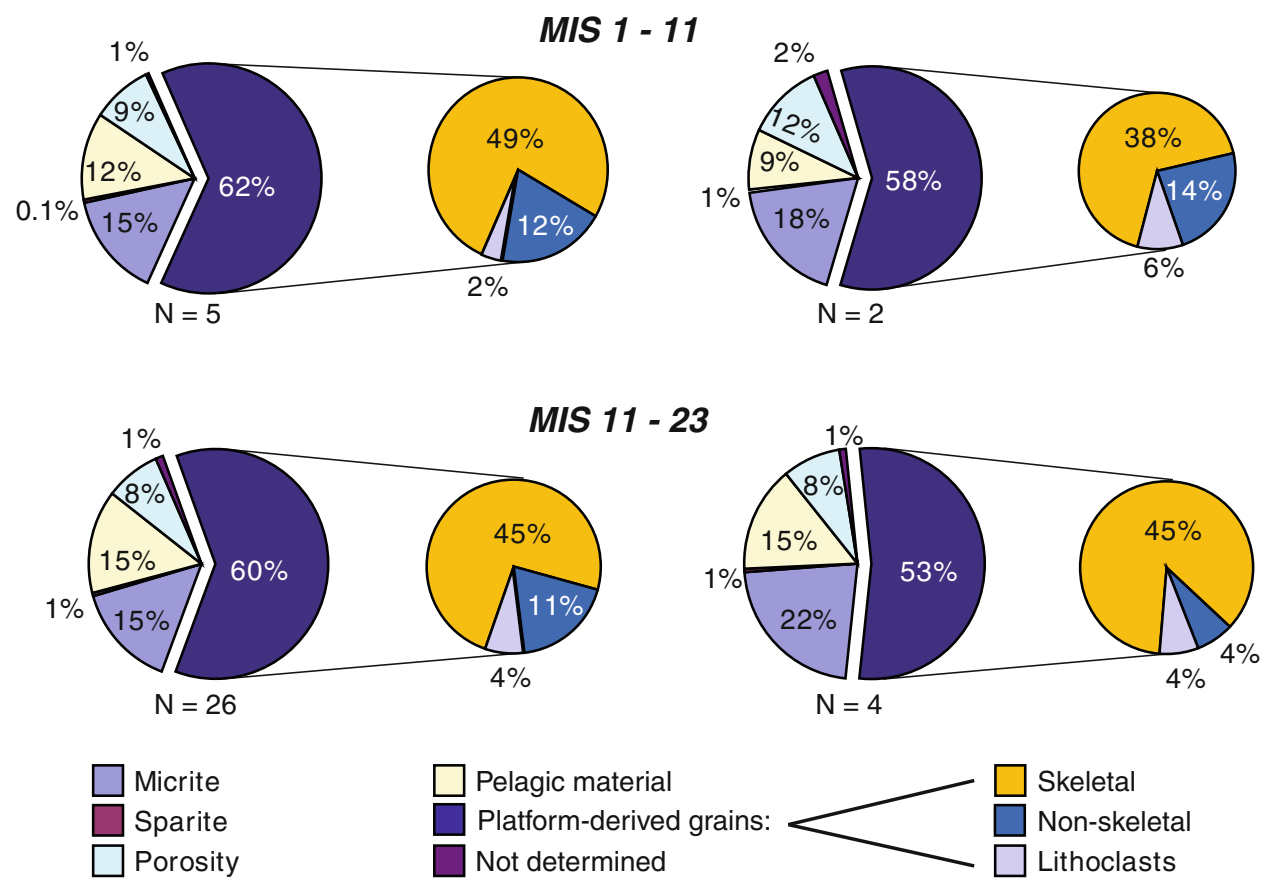

skeletal fraction, but sponges and echinoderms are also found. Pellets with $8 \%$ dominate the non-skeletal grains (Fig. 5b).

The matrix, pelagic-derived clasts, and platform-derived clasts are represented with more or less equal amounts, 30, 35 , and $31 \%$, respectively (Table 1 ; Fig. 6). In the last fraction, skeletal grains are twice as frequent as non-skeletal grains, $20 \%$ versus $10 \%$.
Calciturbidites of MIS 1 to 11

\section{Sea-level highstand calciturbidites}

Thirty-four percent of the counts are micrite; sparite makes up less than $1 \%$ of the samples (Fig. 3). Pellets with $15 \%$ are the dominant constituent of the non-skeletal fraction, ooids occur in minor quantities with $5 \%$. The skeletal 
fraction essentially consists of benthic foraminifers $(6 \%)$, bivalves (3\%), and sponges (3\%) (Fig. 5c).

Once again, the matrix represents roughly one-third of all counts, $34.5 \%$, closely followed by pelagic input with $26.5 \%$. Platform-derived grains represent $34 \%$ of the counts, and these can be subdivided into $22 \%$ non-skeletal and $12 \%$ skeletal grains (Table 1; Fig. 6).

\section{Sea-level lowstand calciturbidites}

More than $45 \%$ on average of the points counted consist of micrite; sparite is almost completely lacking in the thinsections $(0.28 \%)$. The porosity varies around $2 \%$. Benthic foraminifers, bivalves, and echinoderms, represent the skeletal elements while pellets dominate the non-skeletal fraction. Lithoclasts represent less than $1 \%$ (Figs. 3, 5d).

Micrite (45\%) and planktic foraminifers (30\%) dominate in these calciturbidites. Platform-derived components represent $21 \%$ of the grains, in which $12 \%$ are skeletal, and 9\% are non-skeletal grains.

\section{Calcidebrites of MIS 11 to 23}

\section{Sea-level highstand calcidebrites}

Micrite is relatively low with $15 \%$ of the total counts, and even sparite remains below $1 \%$. The composition of the skeletal fraction is rather diverse. Green algae, red algae, bivalves, and benthic foraminifers dominate within this fraction, with $11,8,10$, and $7 \%$, respectively. Calcareous sponges, ostracods, corals, and bryozoans occur in minor amounts. Pellets and ooids occur in equal amounts, both approx. $4 \%$. Porosity may amount to $12 \%$ (Figs. 4, 5e).

In total, the matrix represents only $16 \%$ of the grains counted (Table 1; Fig. 6). Pelagic input follows closely with $15 \%$. The platform-derived components dominate and may reach $60 \%$ within these calcidebrites. These grains mainly consist of skeletal elements $(45 \%)$. Non-skeletal elements and lithoclasts occur in minor quantities, 11 and $4 \%$, respectively.

\section{Sea-level lowstand calcidebrites}

Micrite reaches $22 \%$ and sparite does not surpass $1 \%$ of the counts. The most important skeletal grains are green algae, close to $19 \%$, bivalves with $10 \%$, and benthic foraminifers with $8 \%$. Other constituents occur in minor quantities. This also holds for the non-skeletal grains like pellets and ooids (Figs. 4, 5f).

The matrix average in these calcidebrites varies around $22 \%$. Pelagic grains encompass $15 \%$ of the point counts.
Platform-derived components prevail and represent more than $50 \%$ of the grains. Skeletal grains predominate with $45 \%$, while non-skeletal elements only reach $4 \%$. The porosity on average is $9 \%$ (Table 1; Fig. 6).

\section{Calcidebrites of MIS 1 to 11}

\section{Sea-level highstand calcidebrites}

The micrite fraction reaches $15 \%$ of the matrix, while sparite occurs with less than $1 \%$. Skeletal platform-derived grains dominate with green algae (18\%), bivalves (12\%), benthic foraminifers $(13 \%)$, and corals $(3 \%)$. The nonskeletal fraction shows low values with $8 \%$ pellets and $3 \%$ ooids. The porosity is slightly elevated with $9 \%$. The percentage of non-determined grains remains low with $1 \%$ (Figs. 4, 5g).

The category matrix varies around $16 \%$ and pelagic input around $12 \%$. The platform-derived grains reach values up to $65 \%$ and mainly consist of skeletal grains (50\%) with minor quantities of non-skeletal grains $(12 \%)$ and lithoclasts (2\%) (Table 1; Fig. 6).

\section{Sea-level lowstand calcidebrites}

The micrite represents $18 \%$ of the counts and sparite $1 \%$. The skeletal platform-derived fraction mainly consists of green algae, benthic foraminifers, and bivalves. The nonskeletal fraction of platform-derived grains consists of pellets (13\%) and less than $0.5 \%$ ooids (Figs. $4,5 \mathrm{~h}$ ).

Platform-derived grains reach $58 \%$ in these calcidebrites. The skeletal fraction dominates in this category with $38 \%$, non-skeletal grains and lithoclasts arrive at 14 and $6 \%$, respectively. The matrix remains lower and fluctuates around $19 \%$, while the average pelagic input is approximately $9 \%$. Porosity is relatively important with $12 \%$. Less than $2 \%$ of the grains could not be determined (Table 1; Fig. 6).

\section{Summary of calciturbidites and calcidebrites}

In summary, the point count analysis shows that calciturbidites deposited during highstands of sea level are rich in non-skeletal grains (Table 1; Figs. 5 and 6). Skeletal grains, e.g., benthic foraminifers, echinoderms, and sponges, dominate calciturbidites deposited during lowstands of sea level. In younger deposits, as of MIS 11, all calciturbidites show a higher percentage in micrite. Calcidebrites have a fairly stable composition throughout the succession analyzed. They are rich in skeletal grains, green algae, bivalves, benthic foraminifers, and corals. 


\section{Discussion}

\section{Calciturbidites}

Sedimentation in Exuma Sound is clearly dominated by increased sediment input during highstands in sea level (Reijmer et al. 1988), "highstand shedding" sensu Droxler et al. (1983), Mullins et al. (1984), and Schlager et al. (1994). Carbonate production is high when the shallowwater platform is flooded and the majority of the sediments produced are exported towards the surrounding basins (e.g., Mullins 1983; Droxler et al. 1983; Reijmer et al. 1988; Eberli et al. 1997; Rendle et al. 2000; Roth and Reijmer 2004, 2005; Lantzsch et al. 2007). The glacial periods with low sea level show sharply reduced carbonate production and thus a relative increase in basinal input while the majority of the shallow-water areas are exposed. Lithification of the platform-top sediments takes place shortly after exposure and thus also reduces platform export (Dravis 1979, 1996).

The Pleistocene calciturbidites of Exuma Sound show two different composition modes analogous to earlier studies of Haak and Schlager (1989) in their analysis of calciturbidites deposited in another Bahamian intraplatform basin, the Tongue of the Ocean. Both modes can be related to different positions of sea level. The calciturbidites deposited during interglacial periods, relative highstands in sea level, do contain significant higher amounts of non-skeletal grains rather than skeletal grains (Figs. 3, 6). In contrast, turbidites deposited during glacial periods, relative lowstands in sea level, and show a dominance of skeletal grains (Figs. 3, 6). The non-skeletal grains mainly consist of peloids, pellets, and ooids, grains that dominate the facies realms in the interior of Great Bahama Bank (Purdy 1963a, b; Enos 1974; Reijmer et al. 2009) (Fig. 7). Therefore, these grains will only be produced and exported when the shallow-water realm of the flat-topped carbonate platform is flooded. Exposing these production realms will result in an abrupt halt in production and export of these grains. As a consequence, glacial calciturbidites will almost be completely devoid of these types of non-skeletal grains. Hence, their composition is dominated by skeletal grains derived from the margin and upper slope of the carbonate platform (Fig. 3), with echinoderms and green algae (Halimeda). This pattern was not only observed in Bahamian (Haak and Schlager 1989: Lantzsch et al. 2007) and Caribbean (Pedro Bank; Andresen et al. 2003) periplatform sediments but was also found in sediment export patterns of Triassic calciturbidites (Reijmer et al. 1991, 1994; Reijmer 1998), Cretaceous slope and slope apron deposits (Ferry and Monier 1987; Everts and Reijmer 1995; Everts et al. 1999; Savary and Ferry 2004), Eocene periplatform sediments (Everts 1991), and Miocene slope deposits of the Bahamas (Betzler et al. 2000).
The pores present in the calciturbidite samples are either intergranular pores related to the loose character of the sediments, e.g., peloidal grainstone with some benthic foraminifers (Fig. 5a), or are intragranular pores within benthic and planktic foraminifers and pteropods (Fig. $5 b-d$ ). The thin-sections show that the sediments have undergone little compaction; geochemical analyses of the periplatform oozes of core sections studied showed no diagenetic modifications of the original input signal (Reijmer et al. 1988).

\section{Changes at the MIS 11 boundary}

The frequency of the number of calciturbidites drastically decreases after MIS 11 within the core studied. It decreases from up to six/seven events per interglacial, e.g., MIS 15 and 13, to two, MIS 7 and 5. Calciturbidites are even absent in MIS 9 and 1. In addition, the calciturbidite composition changes while those deposited after MIS 11 do contain a higher percentage of micrite than the ones deposited before this stage (Figs. 3, 6; Table 1). This changeover in frequency and composition might relate to (1) a change in platform morphology and/or (2) a change in basin morphology.

(1) The cause for the aforementioned transition might be found in the fact that MIS 11 is a very long interglacial stage with twice the duration of other interglacial intervals (Droxler and Farrell 2000; Droxler et al. 2003 and references therein). Droxler et al. (2003) proposed that the establishment of modern barrier reefs and atolls related to high amplitude sea-level transgression across the MIS 12 to MIS 11 transition associated with the unusual warm sea-surface temperatures at low latitudes triggered the synchronous and global establishment of modern barrier reefs and atolls. The prolonged warmth and the resulting overall high sea level during MIS 11, more than $20 \mathrm{~m}$ higher than present-day sea level (Kindler and Hearty 2000), might have had an effect on the morphology of the platform, resulting in the development of a distinct barrier reef with a more restricted platform interior in which the formation of non-skeletal grains, e.g., pellets, and the production of mud was facilitated in a better way than before this stage.

(2) The glacial/interglacial rhythm in Core 632A not only shows a decrease in calciturbidite deposition, but also, to a lesser extent, in the bulk sedimentation rates when moving up-core (Reijmer et al. 1988). The upwardthinning trend may depend on the development of the axial valley of Exuma Sound (Fig. 8a, b). Seismic stratigraphy indicates that the upper $95 \mathrm{~m}$ at Site 632 represents the filling of a channel, probably a precursor of the axial valley that currently lies a few kilometers north of the site (Austin Jr et al. 1986) (Fig. 8c, d). As the old 
Fig. 7 Facies distribution on the shallow-water platform of Great Bahama Bank. Mud-rich wackestone $=1.5$;

Wackestone $=2$; Mud-rich packstone $=2.5$;

Packstone $=3$; Mud-lean packstone or poorly washed grainstone $=3.5$;

Grainstone $=4$; Rudstone $=5$. Modified from Reijmer et al. (2009). Grainstones and rudstones (facies 4 and 5) occur at the outer edge of the platform and surround mud-rich wackestones to packstones (facies 1.5-3.5) that dominate in the platform interior situated on the western leeward side of Andros Island. Coarse-grained sediments in the north, west, and south of the bank thus surround a mud-dominated platform interior. This grainsize distribution very precisely reflects current-influenced and protected areas on the platform

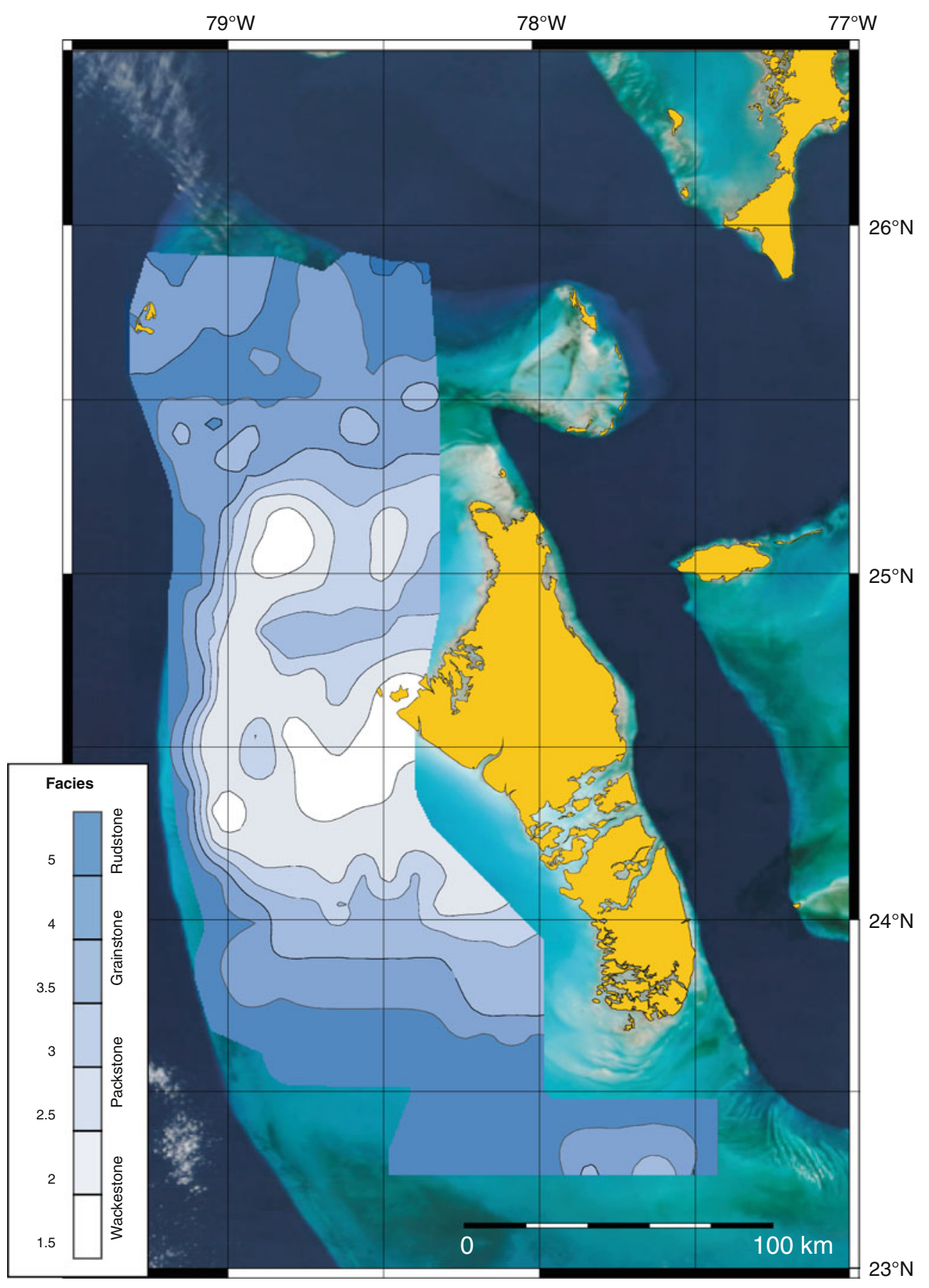

valley filled up, sedimentation rates and turbidite thickness decreased because more turbidity currents were captured by the deepening new valley and were funneled into the nearby Exuma Canyon (Fig. 8c, d). Hence, the trend of mud-richer and less calciturbidites at Site 632 might be the outcome of this change in basin morphology (Reijmer et al. 1988). An increase in upper slope declivity with increasing sea-level amplitudes would result in calciturbidites passing over the site where Site 632A is located. As a consequence, not only the number of calciturbidites deposited would decrease but also the composition of the calciturbidites would change. In this scenario, the muddy tail ends of the calciturbidites would be deposited at this site instead of the relative coarsegrained head of the flow. The proposed morphology change at MIS 11 would also fit into this scenario. Which scenario fits the compositional variations the best, however, remains unsolved. 
Fig. 8 a Location map of selected seismic profiles, Line 03, ES-05, and ES-07, positioned in Exuma Sound, Bahamas. Dark grey pattern indicates islands. Edge of shallow-water carbonate platform marked by $10-\mathrm{m}$ water-depth line. Location of ODP Sites 631, 632, and 633 indicated. b Analogue seismic profile Line 03 crossing Exuma Sound from Cat Island pedestal (NE) to Site 631 location (SW). Steep carbonate slopes flank the northern positioned Exuma Sound channel. c NW-SEoriented segment of Line ES-05 passing over Site 632. Note relocation through time of Exuma Sound Channel position from Site 632 location towards NW. d SW-NE-oriented segment of Line ES-07 crossing Site 632. Location of Site 632 positioned in channel-like sedimentary sequence pinching out towards the NE. All figures modified from Austin Jr et al. (1986)
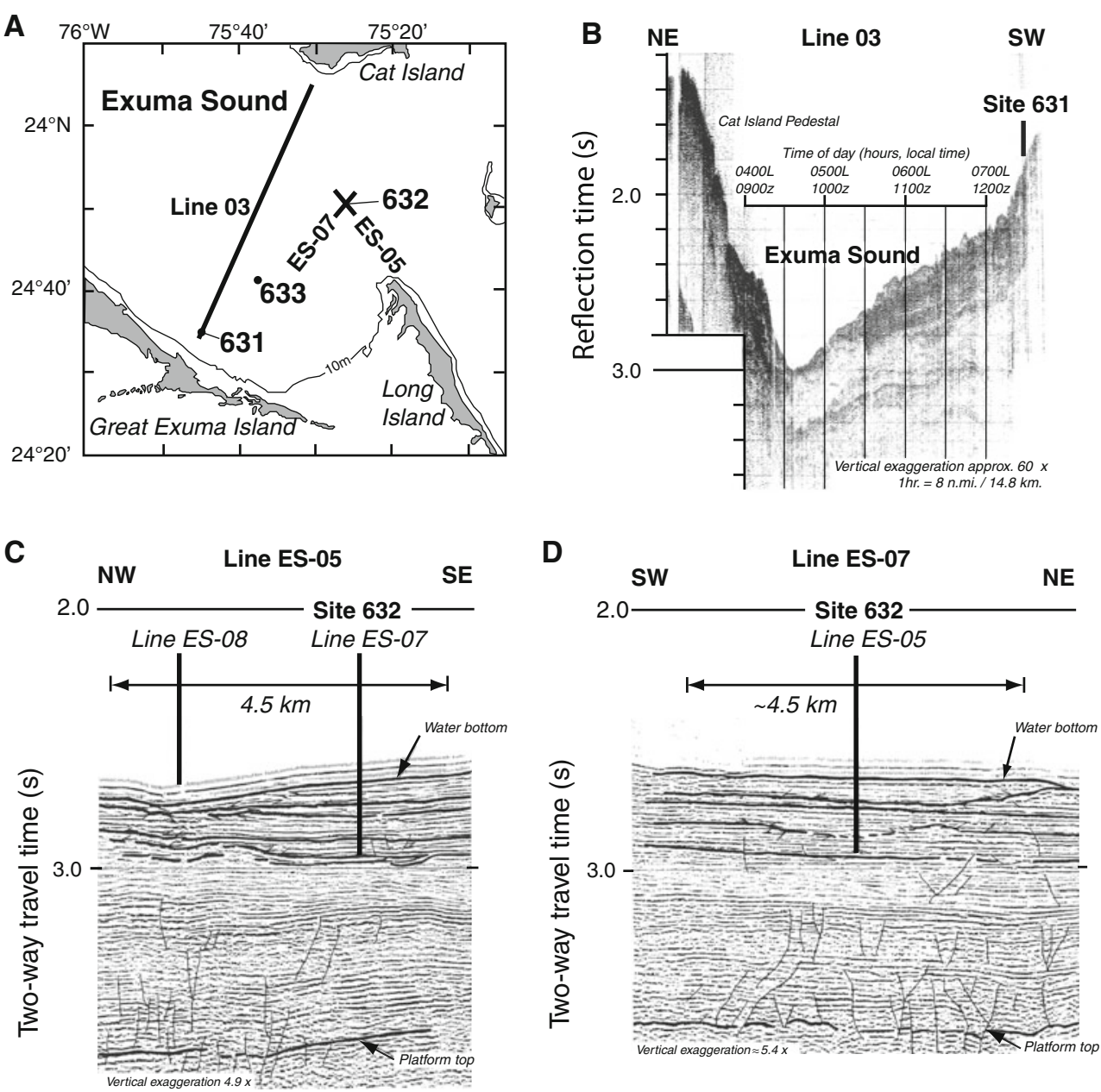

\section{Calcidebrites}

In clastic submarine fan systems, sea-level fluctuations, basinal tectonics, and the rate, type, and nature of sediment supply determine the origin and character of the submarine-fan and related deep-marine clastic systems (Richards et al. 1998). Payros and Pujalte (2008) discussed these factors for calciclastic submarine fans in great detail. They showed that for the source area, the following factors were important: (1) the sediment grain-size-finer-grained sediments have the potential to travel farther into the adjacent basins (Andresen et al. 2003; Rendle-Bühring and Reijmer 2005; Reijmer and Andresen 2007); (2) environmental conditions - the type of facies association in the source area will determine the variation in grain sizes available for transport and the diagenetic potential of the sediments and thus their availability for further transport after initial deposition; (3) the type of sedimentary system-e.g., unrimmed carbonate shelf, carbonate ramp, or a distally steepened slope; (4) windward/leeward effectscalciturbidite and debrite distribution might differ significantly depending on the size of the carbonate sediment producing complex (see for example Holmes Reef in NE Australia, Betzler et al. 1995; Pedro Bank in the Caribbean, Andresen et al. 2003; Great Bahama Bank, Rendle-Bühring and Reijmer 2005); (5) the evolution of the source areawhen a significant amount of sediment is exported and the carbonate system progrades, it will be very likely that mass sediment redistribution occurs; and (6) the slope declivity-the latter will steer the shape of the calciclastic slope fans, slope apron systems in high-angle environments, and point-sourced calciclastic slope fans in systems with a low declivity (below $10^{\circ}$ ) (Payros and Pujalte 2008). A similar series of point-sourced calciturbidite systems were also observed along Great Bahama Bank (Betzler et al. 1999; Eberli et al. 2004). In addition, as for siliciclastic systems, sea level and tectonic processes play a major role in shaping the carbonate submarine fan systems.

The calcidebrites occur predominantly during the transition from interglacial to glacial stages, thus during the transition from high to low sea level, at the beginning of regressions (Fig. 2). Crevello and Schlager (1980) already noted this phenomenon in their analysis of debris flow deposits present in seismic profiles from the northern part 
of Exuma Sound. They proposed that triggering of these debris flows might relate to (1) changes in the hydrostatic pressure on the sediments or (2) wave action affecting the edge of the platform or (3) the combined effect of both processes. Wilber et al. (1990) already discussed the possibility of destabilization of the edges of carbonate platforms during regressions. Other mechanisms that were proposed were tsunamis, catastrophic events resulting from seismic activity, to invoke turbidity currents and calcidebris flows (Cook et al. 1972; Floquet and Hennuy 2003).

The compositional analysis showed that the debrites are almost exclusively composed of neritic skeletal grains like green algae, benthic foraminifers, bivalves, and corals (Figs. 4, 5e-h, 6). These constituents occur at the edge of the platform, the platform margin. The reduced occurrence of micrite within these deposits to some extent supports their origin from the edge of the platform in which grainstones dominate (Reijmer et al. 2009). As of MIS 8, calcidebrites were not encountered anymore in the cores studied (Fig. 2). This might result from the aforementioned change in platform morphology or the fact that calcidebrites pass over the core site and are deposited in a deeper part of the basin (Reijmer et al. 1988).

The majority of the pores, highlighted by the blue epoxy resin (Fig. 5e-h), are intergranular pores related to the coarseness of the sediments and the relative low mud percentage of the calcidebrite sediments (Table 1). Intragranular pores are present within specific grains, e.g., planktic foraminifers (Fig. $5 \mathrm{f}-\mathrm{h}$ ). The thin-sections show that porosity reduction due to compaction was minimal; planktic foraminifers for example are well preserved and show no flattening of their round chambers (Fig. 5e-h). Porosity distortion related to the preparation procedure of loose sediments can be excluded while utmost care was taken handling the ODP sample containers during the epoxy impregnation and thin-section preparation. Geochemical analyses of the background sediments, the periplatform oozes, show no diagenetic modification of the original carbonate mineralogical input signal (Reijmer et al. 1988). Hence, the porosity observed can be interpreted as the original porosity.

In their overview of the factors controlling the deposition of carbonate megabreccias, Spence and Tucker (1997) distinguished processes inherent to the sedimentary system and processes that operate independently. They regard relative sea-level falls as the most likely process to trigger carbonate debris flows. Recent studies, however, have shown that sea-level rises might also result in the deposition of calcidebrites and calciturbidites (Andresen et al. 2003; Lantzsch et al. 2007; Jorry et al. 2010). The composition of the Bahamian calcidebrites agrees with platform edge and upper slope source areas. Spence and Tucker (1997) proposed these areas as sites that are very sensitive to destabilization processes inherent to the sedimentary system, which might result in the generation of calcidebrites. They invoked overpressure, occurring during relative sea-level falls at discrete hydrologically confined horizons beneath the seafloor, and processes set in motion when the platform top becomes subaerially exposed during relative lowstands of sea level, as important mechanisms inducing instability. Spence and Tucker (1997) especially mention the increase in stress within the platform edge and upper slope sediments as pore-fluids drain from the sediment during a sea-level fall. Increased hydrostatic pressure on upper-slope sediments was also proposed as a mechanism triggering turbidity currents and calcidebris flows during a relative rise in sea level (Andresen et al. 2003; Lantzsch et al. 2007). Spence and Tucker (1997) considered seismicity as an independently operating process that could cause gravitational slope instability. Andresen et al. (2003), however, noted that the highstand bundling increased the number of calciturbidite beds during highstands of sea level (Droxler and Schlager 1985), and highstand-shedding patterns did not change significantly in the tectonically active setting of Pedro Bank south of Jamaica. Other independently operating processes triggering calcidebrites might be phases of tectonic activity in foreland-basin settings with associated forebulge steepening and seismic shocks affecting the margins of carbonate platforms present (Payros et al. 1999, 2007; Payros and Pujalte 2008), or tsunamis reorganizing upper slope and platform-margin sediments (Kench et al. 2006; BourrouilhLe Jan et al. 2007). The composition of the calcidebrites in Exuma Sound with their platform edge and upper-slopederived grains, however, show that sea-level fluctuations and associated processes, processes inherent to the sedimentary system, were the main drivers triggering these events (Figs. 5e-h, 6).

\section{Conclusions}

The compositional analysis of a series of calciturbidites and calcidebrites from Exuma Sound, Bahamas, showed that a clear differentiation could be made between the two (Fig. 6). The gravity deposits could be subdivided as a function of the nature of the sediment, calciturbidite or calcidebrite, the MIS in which they were deposited, glacial or interglacial, and the timing of their deposition, before or after MIS 11.

Calciturbidites show a differentiation into highstand and lowstand calciturbidites. Increased non-skeletal input characterizes highstands of sea level (interglacial times), and a dominance of skeletal grains from platform edge and upper slope derived grains typify the lowstand deposits. Calcidebrites possess a totally different composition that 
remained stable throughout the entire sequence, with a mix of pelagic and relative coarse-grained, platform-edgederived grains.

The clear facies differentiation between calciturbidites and calcidebrites will allow us to use their composition as a tool to determine sea-level-induced resedimentation processes of these types of deposit more precisely. The sediment composition may also serve as the tool to separate system-inherent from external-induced events when making sequence stratigraphic interpretations on a basin-wide scale.

Acknowledgments We dedicate this paper to Alfred Haak, our deceased brother-in-arms in calciturbidite research. It was Alfred who sampled and redescribed the cores, but unfortunately could not start the detailed analysis of the samples while he passed away in 1988 . The samples were stored and rediscovered when moving offices. We decided to analyze the samples to continue the research where Alfred had left it. We consider the outcome as an exciting new step in calciturbidite research that seamlessly fits into the innovating calciturbidite research paper published by Haak and Schlager in 1989. VU University Amsterdam and Université de Provence are thanked for financial support. Wynanda Koot and Bouke Lacet of the thin-section laboratory of the VU University Amsterdam are thanked for preparation of the thin-sections. We thank the ODP/TAMU core repository at College Station, Texas, for their assistance with the sampling. Prof. Christian Betzler (Hamburg) and Facies editors Prof. André Freiwald (Wilhelmshaven) and Prof. Maurice Tucker (Bristol) are thanked for their constructive reviews.

Open Access This article is distributed under the terms of the Creative Commons Attribution License which permits any use, distribution, and reproduction in any medium, provided the original author(s) and the source are credited.

\section{References}

Andresen N, Reijmer JJG, Droxler AW (2003) Timing and distribution of calciturbidites around a deeply submerged carbonate platform in a seismically active setting (Pedro Bank, Northern Nicaragua Rise, Caribbean Sea). Int J Earth Sci Geol Rundsch 92(4):573-592

Austin Jr JA, Schlager W, Palmer AA, et al (1986) Leg 101, vol 101. In: Proceedings initial reports (Pt. A). Ocean Drilling Program, College Station, TX

Betzler C, Brachert TC, Kroon D (1995) Role of climate in partial drowning of the Queensland plateau carbonate platform (northeastern Australia). Mar Geol 123:11-32

Betzler C, Reijmer JJG, Bernet K, Eberli GP, Anselmetti FS (1999) Sedimentary patterns and geometries of the Bahamian outer carbonate ramp (Miocene and Lower Pliocene, Great Bahama Bank). Sedimentology 46:1127-1146

Betzler C, Pfeiffer M, Saxena S (2000) Shedding patterns and sedimentary cyclicities in periplatform deposits of a Neogene carbonate platform (Miocene, Great Bahama Bank). Geol Rundsch 89:140-153

Bourrouilh-Le Jan FG, Beck C, Gorsline DS (2007) Catastrophic events (hurricanes, tsunami and others) and their sedimentary records: introductory notes and new concepts for shallow water deposits. Sed Geol 199(1-2):1-11
Chayes F (1956) Petrographic modal analysis. Wiley, New York

Cook HE, McDaniel PN, Mountjoy EW, Pray LC (1972) Allochthonous carbonate debris flows at the Devonian bank ('reef') margins, Alberta, Canada. Bull Can Petrol Geol 20(3):439-497

Crevello PD, Schlager W (1980) Carbonate debris sheets and turbidites, Exuma Sound, Bahamas. J Sediment Petrol 50(4): $1121-1148$

Dravis JJ (1979) Rapid and widespread generation of recent oolitic hardgrounds on a high-energy Bahamian platform, Eleuthera Bank, Bahamas. J Sediment Petrol 49(1):195-208

Dravis JJ (1996) Rapidity of freshwater calcite cementationimplications for carbonate diagenesis and sequence stratigraphy. Sediment Geol 107:1-10

Droxler AW, Farrell JW (2000) Editorial-marine isotope stage 11 MIS 11: new insights for a warm future. Global Planet Change $24: 1-5$

Droxler AW, Schlager W (1985) Glacial versus interglacial sedimentation rates and turbidite frequency in the Bahamas. Geology 13:799-802

Droxler AW, Schlager W, Whallon CC (1983) Quaternary aragonite cycles and oxygen-isotope record in Bahamian carbonate ooze. Geology 11:235-239

Droxler AW, Alley RB, Howard WR, Poore RZ, Burckle LH (2003) Introduction: unique and exceptionally long interglacial marine isotope stage 11: window into earth warm future climate. In: Droxler AW, Poore RZ, Burckle LH (eds) Earth's climate and orbital eccentricity: the marine isotope stage 11 question, Geophysical Monograph Series 137. AGU, Washington, DC, pp 1-14

Dunham RJ (1962) Classification of carbonate rocks according to depositional texture. In: Ham WE (ed) Classification of carbonate rocks-a symposium, vol AAPG Memoir 1. Am Assoc Petrol Geol, Tulsa, pp 108-121

Eberli GP, Swart PK, McNeill DF, Kenter JAM, Anselmetti FS, Melim LA, Ginsburg RN (1997) A synopsis of the Bahamas drilling project: results from two deep core borings drilled on the Great Bahama Bank. In: Eberli GP, Swart PK, Malone MJ, et al (eds) Proceedings of the ocean drilling program, initial reports, vol 166. Ocean Drilling Program, College Station, TX, pp 23-41

Eberli GP, Anselmetti FS, Betzler C, Bernoulli D, Van Konijnenburg $\mathrm{J}-\mathrm{H}$ (2004) Calibration of seismic data from the western margin of Great Bahama Bank with exposed strata in the Maiella Mountains (Italy). In: Grammer GM, Harris PM, Eberli GP (eds) Integration of outcrop and modern analogs in reservoir modeling, AAPG Memoir 81. Am Assoc Petrol Geol, Tulsa, pp 207-250

Embry AF, Klovan JE (1971) A Late Devonian reef tract on northeastern Banks Island, Northwest Territories. Bull Canad Petrol Geol 19:730-781

Enos P (1974) Surface sediment facies of the Florida-Bahamas Plateau. Map Series MC-5 no.4 edn. Geoll Soc Am

Everts A-JW (1991) Interpreting compositional variations of calciturbidites in relation to platform stratigraphy: an example from the Paleogene of SE Spain. Sediment Geol 71:231-242

Everts A-JW, Reijmer JJG (1995) Clinoform composition and margin geometries of a Lower Cretaceous carbonate platform (Vercors, SE France). Palaeogeogr Palaeoclimatol Palaeoecol 119:19-33

Everts A-JW, Schlager W, Reijmer JJG (1999) Carbonate platformto-basin correlation by means of grain-composition logs: an example from the Vercors (Cretaceous, SE France). Sedimentology 46(2):261-278

Ferry S, Monier P (1987) Correspondances entre alternances marnocalcaires de bassin et de plate-forme (Crétacé du SE de la France). Bull Soc Géol France 3(5):961-964

Floquet M, Hennuy J (2003) Evolutionary gravity flow deposits in the Middle Turonian-early Coniacian southern Provence Basin (SE 
France): origins and depositional processes. In: Locat J, Mienert $\mathrm{J}$ (eds) Submarine mass movements and their consequences, vol Natural and technical hazard research series. Kluwer Academic Publishers, Dordrecht, pp 417-424

Haak AB, Schlager W (1989) Compositional variations in calciturbidites due to sea-level fluctuations, Late Quaternary, Bahamas. Geol Rundsch 78(2):477-486

Herbig H-G, Bender P (1992) A eustatically driven calciturbidite sequence from the Dinantian II of the eastern Rheinisches Schiefergebirge. Facies 27:245-262

Hine AC, Wilber RJ, Bane JM, Neumann AC, Lorenson KR (1981) Offbank transport of carbonate sands along open, leeward bank margins: Northern Bahamas. Mar Geol 42:327-348

Jorry SJ, Droxler AW, Francis JM (2010) Deepwater carbonate deposition in response to reflooding of carbonate bank and atolltops at glacial terminations. Quat Sci Rev 29:2010-2026

Kench PS, McLean RF, Brander RW, Nichol SL, Smithers SG, Ford MR, Parnell KE, Aslam M (2006) Geological effects of tsunami on mid-ocean atoll islands: the Maldives before and after the Sumatran tsunami. Geology 34(3):177-180

Kindler P, Hearty PJ (2000) Elevated marine terraces from Eleuthera (Bahamas) and Bermuda: sedimentological, petrographic and geochronological evidence for important deglaciation events during the middle Pleistocene. Global Planet Change 24:41-58

Lantzsch H, Roth S, Reijmer JJG, Kinkel H (2007) Sea-level-related resedimentation processes on the northern slope of Little Bahama Bank (Middle Pleistocene to Holocene). Sedimentology 54:1307-1322

Mullins HT (1983) Modern carbonate slopes and basins of the Bahamas. In: Cook HE, Hine AC, Mullins HT (eds) Platform margin and deep water carbonates, SEPM Short Course No. 12, pp 4.1-4.138

Mullins HT, Heath KC, van Buren HM, Newton CR (1984) Anatomy of a modern open-ocean carbonate slope: northern Little Bahama Bank. Sedimentology 31:141-168

Neumann AC, Land LS (1975) Lime mud deposition and calcareous algae in the bight of Abaco, Bahamas: a budget. J Sediment Petrol 45(4):763-786

Palmieri P (2006) Composition des produits de resédimentation gravitaire au Pléistocène: Cas du bassin d'Exuma Sound, Bahamas. Implications géologiques. Unpublished M.Sc. Thesis, Université Paul Cezanne-Université de Provence, Marseille, France

Palmieri P (2007) Dépots gravitaires carbonates, enregistreurs des variations eustatiques ou des événements tectoniques. Unpublished M.Sc. Thesis, Université de Provence, Marseille, France

Payros A, Pujalte V (2008) Calciclastic submarine fans: an integrated overview. Earth Sci Rev 86:203-246

Payros A, Pujalte V, Orue-Etxebarria X (1999) The south Pyrenean Eocene carbonate megabreccias revisited: new interpretation based on evidence from the Pamplona Basin. Sediment Geol 125:165-194

Payros A, Pujalte V, Orue-Etxebarria X (2007) A point-sourced calciclastic submarine fan complex (Eocene Anotz Formation, western Pyrenees): facies architecture, evolution and controlling factors. Sedimentology 54:137-168

Purdy EG (1963a) Recent calcium carbonate facies of the Great Bahama Bank. 1. Petrography and reaction groups. J Geol 71(3):334-355

Purdy EG (1963b) Recent calcium carbonate facies of the Great Bahama Bank. 2. Sedimentary facies. J Geol 71:472-497

Reijmer JJG (1998) Compositional variations during phases of progradation and retrogradation of a Triassic carbonate platform (Picco di Vallandro/Dürrenstein, Dolomites, Italy). Geol Rundsch 87(3):436-448
Reijmer JJG, Andresen N (2007) Mineralogy and grain-size variations along two carbonate margin-to-basin transects (Pedro Bank, Northern Nicaragua Rise). Sediment Geol 198:327-350

Reijmer JJG, Schlager W, Droxler AW (1988) Site 632: PliocenePleistocene sedimentation cycles in a Bahamian basin. In: Austin Jr. JA, Schlager W, et al (eds) Proceedings of the ocean drilling program, scientific results leg 101, vol 101. Ocean Drilling Program, College Station, TX, pp 213-220

Reijmer JJG, Ten Kate WGHZ, Sprenger A, Schlager W (1991) Calciturbidite composition related to exposure and flooding of a carbonate platform (Triassic, Eastern Alps). Sedimentology 38:1059-1074

Reijmer JJG, Schlager W, Bosscher H, Beets CJ, McNeill DF (1992) Pliocene/Pleistocene platform facies transition recorded in calciturbidites (Exuma Sound, Bahamas). Sediment Geol 78:171-179

Reijmer JJG, Sprenger A, Ten Kate WGHZ, Schlager W, Krystyn L (1994) Periodicities in the composition of Late Triassic calciturbidites (Eastern Alps, Austria). In: De Boer PL, Smith DG (eds) Orbital forcing and cyclic sequences, vol 19. Special Publication. International Association of SedimentologistsBlackwell, London, pp 323-343

Reijmer JJG, Swart PK, Bauch T, Otto R, Reuning L, Roth S, Zechel $S$ (2009) A re-evaluation of facies on Great Bahama Bank I: new facies maps of western Great Bahama Bank. Int Assoc Sediment Spec Publ 41:29-46

Rendle RH, Reijmer JJG, Kroon D, Henderson GM (2000) Mineralogy and sedimentology of the Pleistocene to Holocene on the leeward margin of Great Bahama Bank. In: Eberli GP, Swart PK, Malone MJ, et al. (eds) Proceedings of the ocean drilling program, scientific results leg 166, vol 166. Ocean Drilling Program, College Station, TX, pp 61-76

Rendle-Bühring RH, Reijmer JJG (2005) Controls on grain-size patterns in periplatform carbonates: marginal setting versus glacio-eustasy. Sediment Geol 175(1-4):99-113

Richards M, Bowman M, Reading H (1998) Submarine-fan systems I: characterization and stratigraphic prediction. Mar Petrol Geol 15:689-717

Roth S, Reijmer JJG (2004) Holocene Atlantic climate variations deduced from carbonate periplatform sediments (leeward margin, Great Bahama Bank). Paleoceanography 19(1):PA1003. doi: 10.1029/2003PA000885

Roth S, Reijmer JJG (2005) Holocene millennial to centennial carbonate cyclicity recorded in slope sediments of the Great Bahama Bank and its climatic implications. Sedimentology 52:161-181

Savary B, Ferry S (2004) Geometry and petrophysical parameters of a calcarenitic turbidite lobe (Barremian-Aptian, Pas-de-la-Cluse, France). Sediment Geol 168:281-304

Schlager W, Reijmer JJG, Droxler AW (1994) Highstand shedding of carbonate platforms. J Sediment Res B64(3):270-281

Spence GH, Tucker ME (1997) Genesis of limestone megabreccias and their significance in carbonate sequence stratigraphic models: a review. Sediment Geol 112(3-4):163-193

Vail PR, Audemard F, Bowman SA, Eisner PN, Perez-Cruz C (1991) The stratigraphic signatures of tectonics, eustasy and sedimentology-an overview. In: Einsele G, Ricken W, Seilacher A (eds) Cycles and events in stratigraphy. Springer, Berlin Heidelberg New York, pp 617-659

Wilber RJ, Milliman JD, Halley RB (1990) Accumulation of bank-top sediment on the western slope of Great Bahama Bank: rapid progradation of a carbonate megabank. Geology 18(10):970-974

Wilson PA, Roberts HH (1995) Density cascading: off-shelf sediment transport, evidence and implications, Bahama Banks. J Sediment Res A65(1):45-56 